\title{
Contamination of raw bivalve molluscs available in Poland between 2009 and 2013 with marine biotoxins
}

\author{
Mirosław Michalski, Jacek Osek \\ Department of Hygiene of Food of Animal Origin \\ National Veterinary Research Institute, 24-100 Pulawy, Poland \\ mmichal@piwet.pulawy.pl
}

Received: September 2, 2016 Accepted: November 23, 2016

\begin{abstract}
Introduction: Growing consumption of shellfish is associated with an increased risk of food poisoning. The study was carried out on live bivalve molluscs available on the Polish market between 2009 and 2013. Material and Methods: ELISA was used for the determination of the following marine biotoxins: paralytic shellfish poison (PSP), amnaesic shellfish poison (ASP), and diarrhoeic shellfish poison (DSP). The molluscs, of which seven species were examined, were obtained from wholesale companies and markets. Results: Marine biotoxins were detected below the permitted levels in 67.6\% of the samples. The maximum amounts of PSP and ASP biotoxins were found in great scallops $(532.6 \mu \mathrm{g} / \mathrm{kg}$ and $1.0 \mathrm{mg} / \mathrm{kg}$ respectively) and the peak for DSP was in blue mussels $(107 \mu \mathrm{g} / \mathrm{kg})$. Conclusion: The analysis of toxicological status of raw bivalve molluscs available on the market in Poland indicates that they are safe for consumers.
\end{abstract}

Keywords: raw bivalve molluscs, marine biotoxins, ELISA, Poland.

\section{Introduction}

Microscopic phytoplankton is a primary source of food for marine molluscs such as oysters, clams, scallops, or mussels, and for shellfish larvae. Of 5000 existing species of dinoflagellates and diatoms, 300 can be present in a very large quantity and give rise to algal blooms, also termed "blooming water". Most of them produce marine biotoxins which are harmful for humans $(6,9,10,12,15)$. The term "marine biotoxins" means toxic substances accumulated by bivalve molluscs, in particular as a result of feeding on the plankton containing toxins. These toxins enter the bodies of the molluses in their plankton feed and accumulate in the muscles and hepatopancreas. Serious health problems can appear for consumers of contaminated shellfish after their ingestion because several illnesses are connected with marine biotoxins. They include paralytic shellfish poisoning (PSP) caused by a saxitoxin group; diarrhoeic shellfish poisoning (DSP) induced by liphophilic toxins such as okadaic acid (OA), pectenotoxins (PTX's), yessotoxin (YTA), and azaspiracid (AZA); and amnesic shellfish poisoning (ASP) due to intoxication with domoic acid (DA) and its analogues $(8,14,16,17,24)$. The heat resistance of the toxins means that even well-cooked bivalves might still constitute a risk to human health (3, 6). The occurrence of intoxication symptoms such as nausea, cramps, vomiting, weakness, dysphasia, dysphonia, respiratory paralysis, diarrhoea, abdominal pain, ataxia and memory loss, headaches, disorientation, coma, and varying severity dizziness depends on the individual sensitivity of the human, the type, and the quantity of consumed toxins. The symptoms can appear from a few hours to a few days after ingestion. In extreme cases of contamination death can result $(8,11,12,20)$. This type of food has become more and more popular in Poland. Live bivalve molluscs are cultivated in European countries, delivered to Poland after veterinary control in country of origin, and declared suitable for human consumption. In order to protect consumers, regulatory authorities in Europe, the USA, and elsewhere have established relevant permits. The requirements for the production, harvesting, storage conditions, and use of bivalve shellfish in the food processing industry are described in European Union food legislation. Due to the epidemiological relation between the occurrence of diseases and consumption of raw molluscs, toxicological criteria for these food products have been 
established (21-23). The objective of the study was to evaluate marine biotoxin contamination of live bivalves available for human consumption in Poland.

Table 1. Bivalve molluses used in the study

\begin{tabular}{lll}
\hline $\begin{array}{l}\text { Species of } \\
\text { bivalve mollusc }\end{array}$ & $\begin{array}{l}\text { Country } \\
\text { of origin }\end{array}$ & $\begin{array}{l}\text { Number } \\
\text { of samples }\end{array}$ \\
\hline $\begin{array}{l}\text { Oyster } \\
\text { (Crassostrea } \text { ssp.) }\end{array}$ & $\begin{array}{l}\text { France } \\
\text { Norway } \\
\text { The Netherlands }\end{array}$ & $\begin{array}{l}28 \\
15\end{array}$ \\
\hline & France & 1 \\
Great scallop & Italy & 3 \\
(Pecten maximus) & The Netherlands & 10 \\
& Norway & 13 \\
\hline & Denmark & 2 \\
Blue mussel & Norway & 18 \\
(Mytilus edulis) & Spain & 6 \\
& The Netherlands & 37 \\
\hline $\begin{array}{l}\text { Japanese carpet shell } \\
\text { (Tapes } \text { spp.) }\end{array}$ & France & 9 \\
\hline $\begin{array}{l}\text { Razor clam } \\
\text { (Ensis directus) }\end{array}$ & Italy & 33 \\
\hline Cockle & The Netherlands & 1 \\
(Cerastoderma edule) & The Netherlands & 11 \\
\hline $\begin{array}{l}\text { Dog cockle } \\
\text { (Glycymeris glycymeris) }\end{array}$ & France & 10 \\
\hline
\end{tabular}

\section{Material and Methods}

The study was conducted on live bivalve molluscs as listed in Table 1. They were obtained from wholesale companies and markets in Poland between 2009 and 2013. The samples $(n=206)$ were collected in original packaging (supplier's box or mesh net) and were from different countries of Europe.

After purchasing, the samples were immediately delivered to the laboratory at refrigerated temperature. Following preparation of the shellfish, the meat was frozen and after collection of some samples for analysis the material was thawed and test procedures were followed. For determination of PSP toxins use was made of the Ridascreen Fast PSP SC test (R-Biopharm AG, Germany) with the detection limit of $50 \mu \mathrm{g} / \mathrm{kg}$ of shellfish meat. ASP toxins were identified with the ASP Direct ELISA (Biosense, Norway), and the presence of DSP toxins was tested with the OkaTest (formerly Toxiline DSP) colorimetric phosphatase inhibition assay (Zeu-Inmunotec, Spain), with the limits of detection $0.01 \mathrm{mg} / \mathrm{kg}$ and $63 \mu \mathrm{g} / \mathrm{kg}$ of shellfish meat, respectively. Preparation of samples and tests was performed according to the procedures described by the manufacturers.

\section{Results}

The number of analysed samples and species of bivalve molluscs is shown in Table 2. Percentages of positive samples in each year were from 48.9 up to 84.8.

The results of biotoxin testing are shown in Table 3 . Samples were examined to the total of 206, and in 139 (67.4\%) of them PSP, DSP, or/and ASP toxins were detected. Oysters, scallops, blue mussels, and japanese carpet shells were examined between 2009 and 2013. Cockles were tested in 2009-2010 and dog cockles only in 2009 because their availability on the market was limited. The maximum levels of PSP and ASP biotoxins were found in great scallops $(532.6 \mu \mathrm{g} / \mathrm{kg}$ and $1.0 \mathrm{mg} / \mathrm{kg}$ respectively) and where DSP was most concentrated was in blue mussels $(107 \mu \mathrm{g} / \mathrm{kg})$. Only dog cockle molluscs were free of PSP. ASP toxin was not detected in blue mussels, japanese carpet shells, razor clams, or dog cockles. Biotoxins from the DSP group were not identified in razor clams or dog cockles.

Table 2. Number of samples of bivalve molluscs tested and number of samples with biotoxins

\begin{tabular}{|c|c|c|c|c|c|c|c|c|c|c|}
\hline \multirow{2}{*}{ Species } & \multicolumn{2}{|c|}{2009} & \multicolumn{2}{|c|}{2010} & \multicolumn{2}{|c|}{2011} & \multicolumn{2}{|c|}{2012} & \multicolumn{2}{|c|}{2013} \\
\hline & Tested & Positive & Tested & Positive & Tested & Positive & Tested & Positive & Tested & Positive \\
\hline Oyster & 11 & 6 & 6 & 5 & 10 & 7 & 11 & 7 & 11 & 6 \\
\hline Great scallop & 5 & 3 & 7 & 5 & 7 & 7 & 3 & 3 & 5 & 5 \\
\hline Blue mussel & 13 & 5 & 16 & 13 & 11 & 9 & 13 & 7 & 10 & 8 \\
\hline Japanese carpet shell & 7 & 4 & 8 & 7 & 10 & 8 & 9 & 5 & 9 & 8 \\
\hline Razor clam & - & - & - & - & 2 & 2 & 4 & 1 & 5 & 2 \\
\hline Cockle & 7 & 4 & 4 & 2 & - & - & - & - & - & - \\
\hline Dog cockle & 2 & 0 & - & - & - & - & - & - & - & - \\
\hline $\begin{array}{l}\text { Total/positive } / \% \text { of } \\
\text { positive }\end{array}$ & \multicolumn{2}{|c|}{$45 / 22 / 48.9$} & \multicolumn{2}{|c|}{$41 / 32 / 78.0$} & \multicolumn{2}{|c|}{$40 / 33 / 84.4$} & \multicolumn{2}{|c|}{$40 / 23 / 57.5$} & \multicolumn{2}{|c|}{$40 / 29 / 72.5$} \\
\hline
\end{tabular}

Table 3. Results of identification of biotoxins in shellfish samples

\begin{tabular}{|c|c|c|c|c|}
\hline Species & $\begin{array}{l}\text { Number of samples: } \\
\text { tested/positive }\end{array}$ & PSP $(\mu \mathrm{g} / \mathrm{kg})$ & $\operatorname{ASP}(\mathrm{mg} / \mathrm{kg})$ & $\mathrm{DSP}(\mu \mathrm{g} / \mathrm{kg})$ \\
\hline Oyster & $49 / 31$ & $50.7-266.2$ & $0.2-0.5$ & $63-102$ \\
\hline Great scallop & $27 / 23$ & $51.5-532.6$ & $0.5-1.0$ & 63 \\
\hline Blue mussel & $63 / 52$ & $50.0-516.9$ & - & $63-107$ \\
\hline Japanese carpet shell & $43 / 32$ & $52.4-88.5$ & - & $63-92$ \\
\hline Razor clam & $11 / 5$ & $52.6-54.3$ & - & - \\
\hline Cockle & $11 / 6$ & $51.5-82.4$ & 0.3 & 63 \\
\hline Dog cockle & $2 / 0$ & - & - & - \\
\hline Range & & $50.0-532.6$ & $0.2-1.0$ & $63-107$ \\
\hline Maximum legal limit & & $800 \mu \mathrm{g} / \mathrm{kg}$, as saxitoxin & $20 \mathrm{mg} / \mathrm{kg}$, as domoic acid & $160 \mu \mathrm{g} / \mathrm{kg}$, as okadaic acid \\
\hline
\end{tabular}




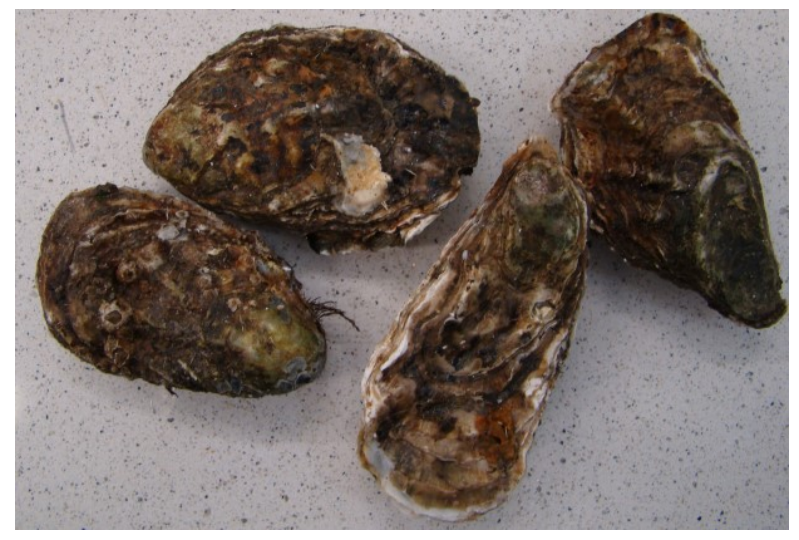

Fig. 1. Oysters

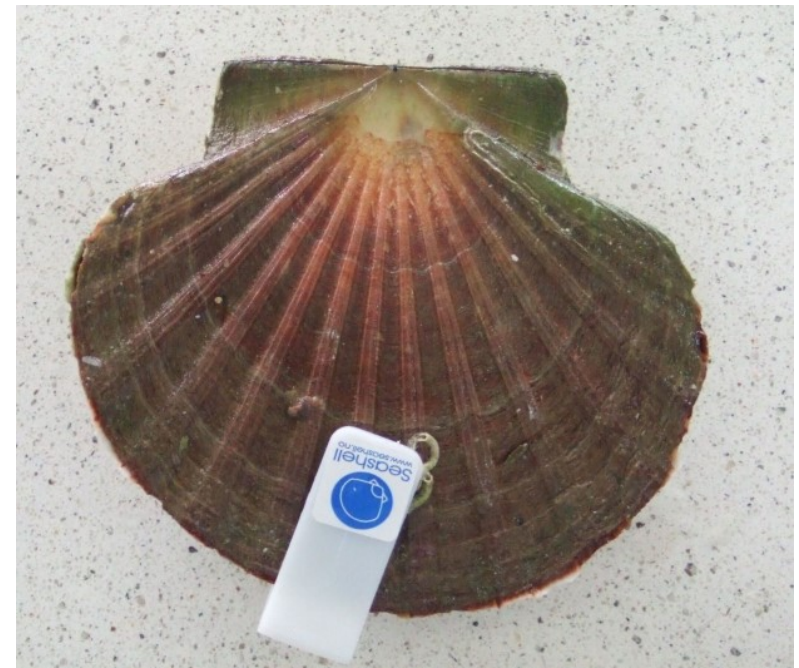

Fig. 2. Great scallop

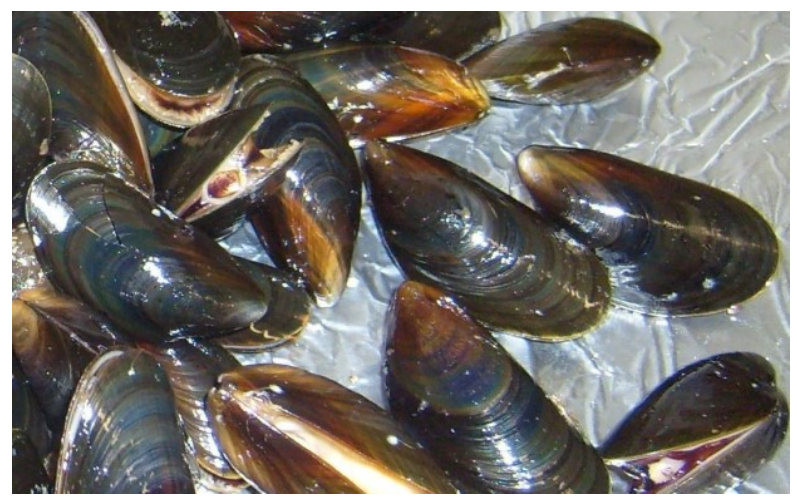

Fig. 3. Blue mussels

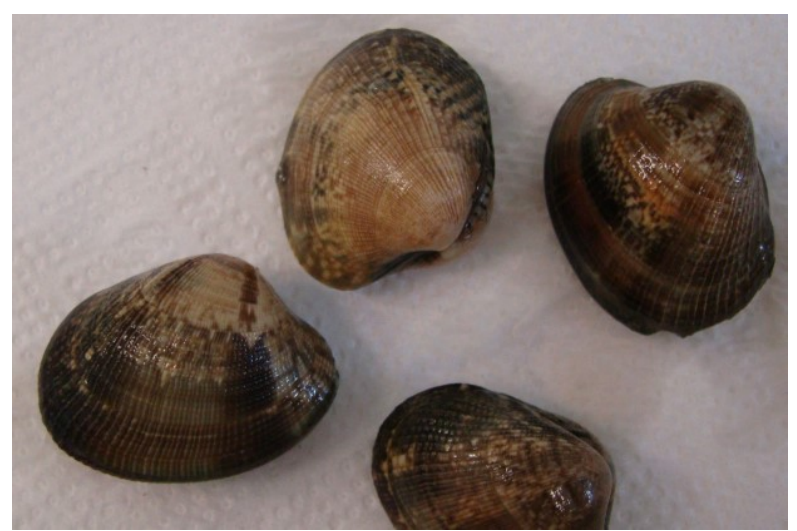

Fig. 4. Japanese carpet shells

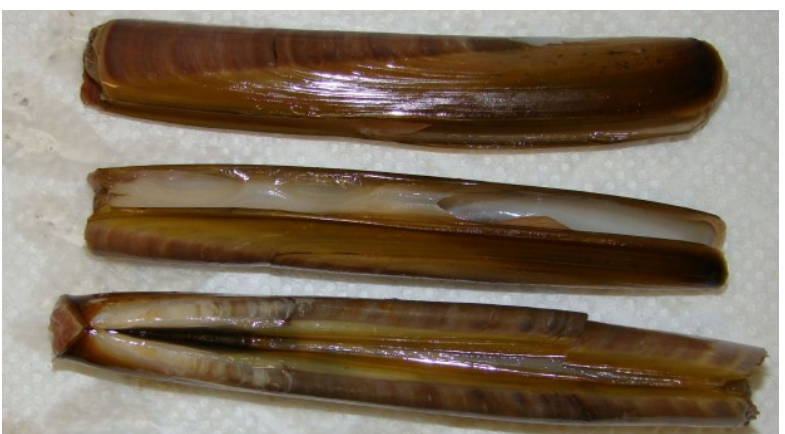

Fig. 5. Razor clams

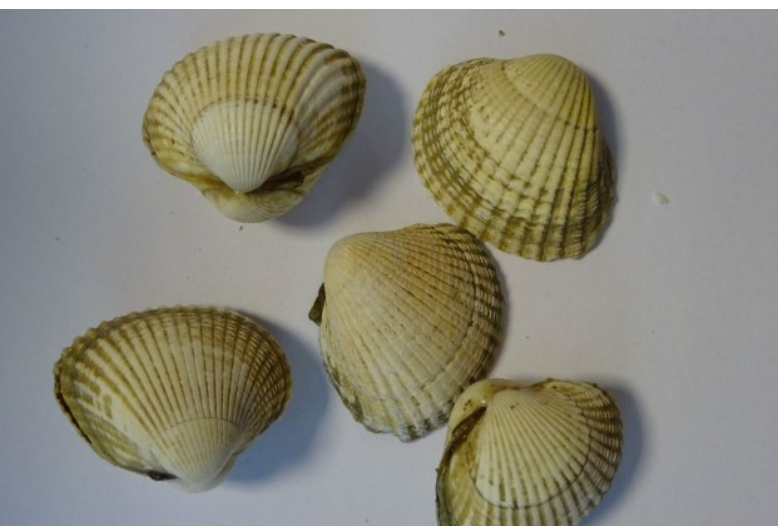

Fig. 6. Cockles

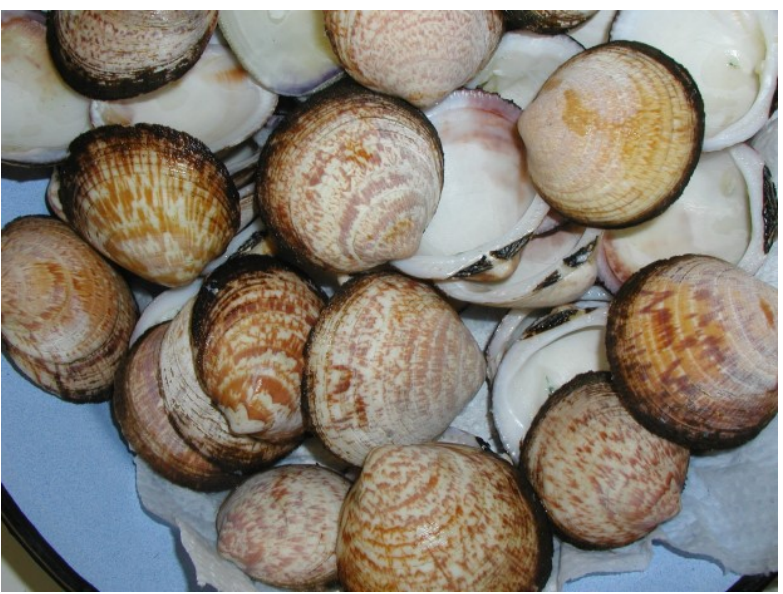

Fig. 7. Dog cockles

\section{Discussion}

Due to a global increase in production and consumption of shellfish, there is a higher need for ensuring protection of consumer health. Likewise in Poland food of marine origin (seafood) continues to expand its market. Bivalve molluscs may be a serious safety concern when consumed raw or cooked, due to the presence of toxicological hazards $(10,11)$. DSP toxins were detected in mussels from the Adriatic Sea but without resulting in any serious illnesses in consumers (1). Canada reported the first intoxication by DSP associated with cooked mussels in 2011 when 62 clinical cases were shown (24). On a global basis, almost 2000 intoxications of humans with PSP are reported per year with a $15 \%$ mortality rate (2). In 
Portugal in 2003-2006, 15,175 official samples with the maximum shellfish meat DSP and ASP concentrations of $659 \mu \mathrm{g}$ of $\mathrm{OA} / 100 \mathrm{~g}$ and $148 \mu \mathrm{g} / \mathrm{g}$ respectively were identified. Also in Portugal, PSP in mussels reached the level of $1590 \mu \mathrm{g} / 100 \mathrm{~g}$ shellfish meat in 2005-2006. These toxins were examined mainly in blue mussels, Japanese carpet shells, and razor clams (25). Only DSP biotoxins were present in mussels from northern Adriatic waters in 1989 and 1991 (26). The bivalve molluscs were free of PSP and ASP during these years (26). Monitoring of lipophilic marine toxins was carried out in three shellfish production sites on the West Coast of Ireland. In mussels (M. edulis), DSP was detected at a maximum level of $645 \mu \mathrm{g} / \mathrm{kg}$. Mussels with more than $160 \mu \mathrm{g} / \mathrm{kg}$ of the toxin were not used for consumption (7). In Sweden in 1994, almost $5000 \mu \mathrm{g} / \mathrm{kg}$ of DSP in mussel meat was found (13). In 1997, only three samples contained DSP above the restriction level for this biotoxin. (13). From autumn 1989 to spring 1990 and from early autumn 2000 to early 2001, high levels of toxins (about 200 to $2000 \mu \mathrm{g}$ DTX/kg of mussel meat) were recorded during 26 weeks (13). The first identified DSP toxins of the Mediterranean coast of Morocco were in oysters and clams from the Nador area in 1999 and in 2003 respectively. On the Atlantic coast, the first discovery of these toxins was in clams in 1999 and then in oysters in 2000. In 2003, DSP was detected in bivalve molluscs from the Atlantic with a maximum level of $140 \mu \mathrm{g} / \mathrm{kg}$ (5). In Poland, only the determination of PSP, DSP, and ASP toxins is performed in the National Veterinary Research Institute. These toxins were found at maximum levels of $756 \mu \mathrm{g} / \mathrm{kg}, 88 \mu \mathrm{g} / \mathrm{kg}$, and $6.3 \mathrm{mg} / \mathrm{kg}$ respectively but all were below the legal limits $(18,19)$. However, the safety of this kind of seafood can be guaranteed mainly by preventive measures and application of appropriate procedures such as suitable selection of harvesting areas, programmes for monitoring of water quality, final product inspections, appropriate methods of analysis, and hygiene control for food business operators involved in the whole food chain $(4,21,22)$. This study showed that the shellfish available on the Polish market were safe for the consumers.

Conflict of Interests Statement: The authors declare that there is no conflict of interests regarding the publication of this article.

Financial Disclosure Statement: The investigation was supported by the Polish Ministry of Agriculture and Rural Development (within the framework of the Multiannual Programme "Protection of animal and public health").

Animal Rights Statement: None required.

\section{References}

1. Ciminiello P., Fattorusso E., Forino., Magno S., Poletti R., Viviani R.: Isolation of 45-hydroxyessotoxin from mussels of the Adriatic Sea. Toxicon 1999, 37, 689-693.

2. Dolah F.M.: Marine algal toxins: Origins, health, effects and their increased occurrence. Environ Health Perspect 2000, 108, 133-141.

3. van Egmond H.P.: Paralytic and diarrhoeic shellfish poisons: occurrence in Europe, toxicity, analysis and regulation. J Nat Toxins 1993, 2, 41-83.

4. van Egmond H.P., Jonker K.M., Poelman M., Scherpenisse P., Stern A.G.: Proficiency studies on the determination of paralytic shellfish poisoning toxins in shellfish. Food Addit Contam 2004, $21,331-340$

5. Elgarch A., Vale P., Rifai S., Fassouane A.: Detection of diarrheic shellfish poisoning and azaspiracid toxins in Moroccan mussels: Comparison of the LC-MS method with the commercial immunoassay kit. Mar Drugs 2008, 6, 587-594, doi: $10.3390 /, \mathrm{d} 6040587$.

6. European Food Safety Authority (EFSA): Marine biotoxins in shellfish - Summary on regulated marine biotoxins EFSA J 2009, 1306, 1-23, doi: 10.2903/j.efsa.2009.1306.

7. Fux E., Bire R., Hess P.: Comparative accumulation and composition of lipophilic marine biotoxins in passive samplers and in mussels (M. edulis) on the West Coast of Ireland. Harmful Algae 2009, 8, 523-537, http://dx.doi.org/10.1016/j.hal.2008. 10.007 .

8. Grant K.S., Burbacher T.M., Faustman E.M., Grattan L.: Domoic acid: neurobehavioral consequences of exposure to a relevant marine biotoxin. Neurotoxicol Teratol 2010, 32, 134 141.

9. Hallegraeff G.M.: Harmful algal blooms: a global overview. In: Manual on Harmful Marine Microalgae., IOC Manuals and Guides No. 33. UNESCO, 1995, pp. 1-22.

10. Huss H.H., Ababouch L., Gram L.: Assessment and management of seafood safety and quality. FAO Fisheries Technical Paper No. 444, Rome, 2003, pp. 19-84.

11. James K.J., Carey B., O'Halloran J., van Pelt F.N.A.M., Škrabáková Z.: Shellfish toxicity: Human health implications of marine algal toxins. Epidemiol Infect 2010, 138, 927-940.

12. Jorgensen K., Scanlon S., Jansen L.B.: Diarrhetic shellfish poisoning toxin esters in Danish blue mussels and surf clams. Food Add Contam 2005, 22, 743-751.

13. Karlson B., Rehnstam-Holm A.S., Loo L.: Temporal and spatial distribution of diarrhetic shellfish toxins in blue mussels, Mytilus edulis (L.), on the Swedish west coast, NE Atlantic. 1988-2005, SMHI Reports Oceanography 2007, 35, 1-40.

14. Lefebvre K.A., Robertson A.: Domoic acid and human exposure risks: A review. Toxicon 2010, 56, 218-230.

15. Lindahl O.: Occurrence and monitoring of harmful algae in the marine environment. In: Mycotoxins and phycotoxins developments in chemistry, toxicology and food safety. Proc. IX Int. IUPAC Symposium on mycotoxins and phycotoxins. 1998, pp. 409-423.

16. Michalski M.: Diarrhetic shellfish poisoning (DSP) as a risk for consumer health. Med Weter 2010, 66, 530-533.

17. Michalski M.: Amnesic shellfish poisoning (ASP) as a risk for consumer health. Med Weter 2011, 67, 599-603.

18. Michalski M., Grądziel-Krukowska K., Osek J.: Occurrence of saxitoxine (PSP marine biotoxins) in live molluscs available on Polish market. Bull Vet Inst Pulawy 2013, 57, 525-528.

19. Pomykała R., Michalski M., Jóźwik A., Osek J.: Microbiological and marine biotoxins contamination of raw bivalve molluscs commercially available in Poland. Bull Vet Inst Pulawy 2012, $56,563-568$

20. Quiliam M.A., Wright J.L.: The amnesic shellfish poisoning mystery. Anal Chem 1989, 61, 1053-1106. 
21. Regulation (EC) No. 852/2004 of the European Parliament and of the Council of 29 April 2004 on the hygiene of foodstuffs. OJ L 139, 30.04.2004.

22. Regulation (EC) No. 853/2004 of the European Parliament and of the Council of 29 April 2004 laying down specific hygiene rules for food of animal origin. OJ L 139, 30.4.2004.

23. Regulation (EC) No. 2074/2005 of 5 December 2005 laying down implementing measures for certain products under Regulation (EC) No. 853/2004 of the European Parliament and of the Council and for the organisation of official controls under Regulation (EC) No. 854/2004 of the European Parliament and of the Council and Regulation (EC) No. 882/2004 of the European Parliament and of the Council, derogating from Regulation (EC) No. 852/2004 of the European Parliament and of the Council and amending Regulations (EC) No. 853/2004 and (EC) No. 854/2004. OJ L338, 25.12.2005.
24. Taylor M., McIntyre L., Ritson M., Stone J., Bronson R., Bitzikos O., Rourke W., Galanis E.: Outbreak of diarrhetic shellfish poisoning associated with mussels, British Columbia, Canada. Mar Drugs 2013, 1, 1669-1676, doi:10.3390/ md11051669.

25. 25. Vale P., Rodrigues S.M., Gomes S.S., Sampayo M.A.: Two decades of marine biotoxin monitoring in bivalves from Portugal (1986-2006).: A review of exposure assessment. Harmful Algae 2008, 7, 11-25, doi.10.1016/j.hal.2007.05.002.

26. Viviani R., Boni L., Cattani O., Milandri A., Poletti R., Pompei M., Sansoni G.: ASP, DSP, NSP and PSP monitoring in mucialagious aggregates and in mussels in a coastal area of the Northern Adriatic Sea facing Emilia-Romagana in 1988, 1989 and 1991. Sci Total Environ 1995, 165, 203-211, doi: 10.1016/0048-9697(95)04553-D. 